\title{
Development and Validation of a Novel UV Spectrophotometric Method for Simultaneous Analysis of Amlodipine, Indapamide and Perindopril
}

\author{
ERICA ALVES, CELINA NAZARETH* and SANELLY PEREIRA \\ Department of Pharmaceutical Chemistry, PES's Rajaram and Tarabai Bandekar College of Pharmacy, Farmagudi, Goa- \\ 403401, India
}

Alves et al.: Novel UV Spectrophotometric Method for Amlodipine, Indapamide and Perindopril

\begin{abstract}
A simple, accurate, precise and economical ultraviolet spectrophotometric method has been developed for the simultaneous estimation of amlodipine, perindopril and indapamide. The developed method was based on determination of the three drugs using ultraviolet absorbance correction method. The three wavelengths chosen were $365 \mathrm{~nm}$ for amlodipine (as absorbances due to other two drugs were nil at this wavelength), $245 \mathrm{~nm}$ for indapamide (corrected for absorbance due to amlodipine) and $204 \mathrm{~nm}$ for perindopril (corrected for absorbances due to amlodipine and indapamide) with water as diluent. The Beer Lambert's range for the three drugs was $10-60 \mu \mathrm{g} / \mathrm{ml}, 5-20 \mu \mathrm{g} / \mathrm{ml}$ and $10-100 \mu \mathrm{g} / \mathrm{ml}$ for amlodipine, indapamide and perindopril respectively, with correlation coefficient $\left(r^{2}\right)$ of $\geq 0.999$. The developed method was validated as per International Conference on Harmonisation guidelines and was found to be accurate, precise, sensitive and robust. The percentage assay results were within acceptable limits. Hence the developed method can be successfully used for the routine analysis of amlodipine, perindopril and indapamide in bulk and in combination.
\end{abstract}

Key words: Absorbance correction method, amlodipine besylate, indapamide, perindopril tert-butyl amine, International Conference on Harmonisation (ICH) guidelines

Amlodipine (AMD), an antihypertensive drug belongs to the group of drugs called dihydropyridine calcium channel blockers. It is commonly used in the treatment of high blood pressure and angina. It also has antioxidant properties and ability to enhance the production of nitric oxide (NO), an important vasodilator that decreases blood pressure. Perindopril (PD) is a nonsulfhydryl prodrug belonging to the angiotensin-converting enzyme (ACE) inhibitor class of medication. It is rapidly metabolized in the liver to its active metabolite perindoprilat, following oral administration. It acts by inhibiting $\mathrm{ACE}$ and therefore prevents the conversion of angiotensin I to angiotensin II; consequently, angiotensin II mediated vasoconstriction and angiotensin II mediated aldosterone secretion from the adrenal cortex are inhibited thus resulting in decreased blood pressure ${ }^{[1]}$. Indapamide (IND), a thiazide-like diuretic results in an overall decrease in blood pressure through its diuretic action (increase in urine output) and vasodilatory properties (inhibiting influx of calcium or

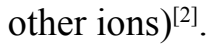

*Address for correspondence

E-mail: celinanaz@yahoo.com

September-October 2020
Literature survey revealed the availability of various chromatographic methods such as Thin-layer chromatography (TLC) ${ }^{[3]}$, Reversed Phase-High Performance Liquid Chromatography (RP-HPLC) [4-7], stability indicating High Performance Liquid Chromatography (HPLC) ${ }^{[8]}$ and Ultraviolet (UV) spectroscopic methods ${ }^{[9-14]}$ like simultaneous equations method, derivative spectroscopy and absorbance correction method for analysis of only two drugs in combination. UV spectroscopic methods have the advantage of being simple, rapid and cost effective. Hence it would be worthwhile to develop a novel UV spectroscopic method for the simultaneous estimation of amlodipine besylate, indapamide and perindopril tert-butyl amine in combination ${ }^{[15,16]}$.

This is an open access article distributed under the terms of the Creative Commons Attribution-NonCommercial-ShareAlike 3.0 License, which allows others to remix, tweak, and build upon the work non-commercially, as long as the author is credited and the new creations are licensed under the identical terms

Accepted 07 October 2020 Revised 27 August 2020 Received 13 March 2020 Indian J Pharm Sci 2020;82(5):843-850 


\section{MATERIALS AND METHODS}

AMD was supplied by Alkem Laboratories Ltd. (Mumbai, India), PD was supplied by Glenmark Pharmaceuticals (Goa, India) and IND was supplied by Adock Ingram Ltd. (Bangalore, India). Synthetic mixture containing $10 \mathrm{mg}$ each of AMD and PD and $2.5 \mathrm{mg}$ of IND was prepared inhouse. Methanol used was of spectroscopic grade. The analysis was carried out on Shimadzu 1800 double beam UV spectrophotometer. The software used was UV Probe.

\section{Preparation of standard stock solution $(1000 \mu \mathrm{g} / \mathrm{ml})$ :}

About $25 \mathrm{mg}$ each of AMD, IND and PD standards were weighed and transferred separately into three $25 \mathrm{ml}$ volumetric flask. Volume was made up to $25 \mathrm{ml}$ with methanol to obtain stock solutions of each drug $(1000 \mu \mathrm{g} / \mathrm{ml})$.

\section{Preparation of working standard solutions:}

Stock solutions of AMD, IND and PD were diluted with distilled water to obtain working standard solutions in the concentration ranges of $10-100 \mu \mathrm{g} / \mathrm{ml}$ for AMD and PD and 5-100 $\mu \mathrm{g} / \mathrm{ml}$ for IND.

\section{Preparation of mixed standard solution of drugs:}

About $1 \mathrm{ml}$ stock solution of each drug was diluted to $10 \mathrm{ml}$ with distilled water to obtain a solution of $100 \mu \mathrm{g} / \mathrm{ml}$ concentration. From this, a mixed drug standard solution was prepared by taking $1 \mathrm{ml}$ each of AMD and PD and $0.25 \mathrm{ml}$ of IND into a $10 \mathrm{ml}$ volumetric flask. Volume was adjusted to the mark with distilled water to obtain a concentration of $10 \mu \mathrm{g} / \mathrm{ml}$ for AMD, PD and $2.5 \mu \mathrm{g} / \mathrm{ml}$ for IND.

\section{Selection of analytical wavelength:}

Working standard solutions of AMD, IND and PD $(10 \mu \mathrm{g} / \mathrm{ml}$ each) were scanned in the range of $200-400$ $\mathrm{nm}$ against the blank and the spectra were recorded. The choice of the analytical wavelengths for analysis was made using the concept of absorbance corrected for interference. Accordingly, three wavelengths were selected: $\lambda_{1}$ for AMD as absorbances due to other two drugs were nil at this wavelength, $\lambda_{2}$ of absorbance of IND and AMD (corrected for absorbance due to AMD) and $\lambda_{3}$ of absorbance of PD, IND and AMD (corrected for absorbances due to AMD and IND).

\section{Determination of Absorptivity:}

The absorbance of the working standard solutions was recorded at their predetermined wavelengths. Calibration curves were plotted and absorptivity values for the drugs were calculated.

\section{Method Validation:}

\section{Linearity}

To determine linearity range for the drugs, a series of working standard solutions were prepared from the respective stock solutions of drugs. A volume of $0.125 \mathrm{ml}, 0.25 \mathrm{ml}, 0.5 \mathrm{ml}, 0.75 \mathrm{ml}, 1 \mathrm{ml}, 1.25 \mathrm{ml}$, $1.5 \mathrm{ml}, 1.75 \mathrm{ml}, 2 \mathrm{ml}, 2.25 \mathrm{ml}$ and $2.5 \mathrm{ml}$ of stock solution of each drug was pipetted into $25 \mathrm{ml}$ volumetric flasks and volume was made up with distilled water to obtain solutions in concentration range of $10-100 \mu \mathrm{g} / \mathrm{ml}$ for AMD and PD and 5-100 $\mu \mathrm{g} /$ $\mathrm{ml}$ for IND. Absorbance of the solutions were recorded at predetermined wavelengths and calibration curves of absorbance vs. concentration were plotted. The linear regression equations and correlation coefficients $\left(\mathrm{r}^{2}\right)$ were determined.

\section{Precision}

Precision analysis was carried out by performing intraday and inter-day precision studies. About $0.5 \mathrm{ml}$ of mixed standard solution of drugs was pipetted into three $25 \mathrm{ml}$ volumetric flasks and volume was made up to the mark with distilled water. Absorbance of the solutions was recorded against blank at predetermined wavelengths. Concentration of each drug was determined using the equations with their respective absorptivity values. Intra-day precision was performed by repeating the procedure thrice in a day while inter-day precision studies were performed on three consecutive days in triplicate.

\section{Accuracy}

The accuracy of the developed method was verified by performing percentage recovery studies at $80 \%$, $100 \%$ and $120 \%$. About $2 \mathrm{mg}$ of placebo powder was weighed and transferred into nine volumetric flasks of $25 \mathrm{ml}$ capacity. To the three sets of flasks (consisting of three flask each), the mixed standard solution of drugs in a volume of $0.4 \mathrm{ml}(80 \%$ level $), 0.5 \mathrm{ml}$ (100\% level) and $0.6 \mathrm{ml}$ (120\% level) was added. About $20 \mathrm{ml}$ of distilled water was added to all the three sets and sonicated for about $5 \mathrm{~min}$. After sonication volume was made up to $25 \mathrm{ml}$ with the diluent and filtered through a Whatman filter paper. Absorbance of the filtrate was recorded at predetermined wavelengths 
against blank. Sample was prepared in a similar manner omitting the drug.

\section{Limit of detection (LOD)}

LOD was calculated using slope and standard deviation response of calibration curves of drugs at the particular wavelength. $\mathrm{DL}=3.3 \sigma / \mathrm{S}$, where, $\sigma-$ standard deviation of response (y intercept) S- slope of calibration curve.

\section{Limit of quantitation (LOQ)}

LOQ was calculated using slope and standard deviation response of calibration curves of drugs at the particular wavelength.

$\mathrm{QL}=10 \sigma / \mathrm{S}$, where, $\sigma$-standard deviation of response (y intercept), S-slope of calibration curve

\section{Robustness}

The robustness of the method was verified by performing the assay of the mixed standard solution. Deliberate minor changes were introduced in experimental conditions such as use of different UV spectrophotometer; change of analyst and by altering the composition of the diluent. The percentage assay values were determined.

\section{Assay of synthetic mixture of drugs:}

A quantity of synthetic mixture equivalent to $12.5 \mathrm{mg}$ of AMD was accurately weighed and transferred to a $25 \mathrm{ml}$ volumetric flask. About $20 \mathrm{ml}$ of methanol was added and dissolved by shaking for about $5 \mathrm{~min}$. The volume was made up to $25 \mathrm{ml}$ with methanol. The solution was filtered through a Whatman filter paper no. 1. From the filtrate, $0.5 \mathrm{ml}$ was withdrawn and transferred to a $25 \mathrm{ml}$ volumetric flask in triplicate and volume was made up to the mark with distilled water. Absorbance of these solutions were recorded at predetermined wavelengths i.e. $\lambda_{1}, \lambda_{2}$ and $\lambda_{3}$ and respective absorbance values were noted as $A_{1}, A_{2}$ and $\mathrm{A}_{3}$.

\section{Concentration of each drug was determined using the following equations:}

$\mathrm{A}_{1}=\mathrm{ax}_{1} \mathrm{Cx}, \mathrm{A}_{2}=\mathrm{ax}_{2} \mathrm{Cx}+\mathrm{ay}_{2} \mathrm{Cy}, \quad \mathrm{A}_{3}=\mathrm{ax}_{3} \mathrm{Cx}+\mathrm{ay}_{3} \mathrm{Cy}+\mathrm{az}_{3} \mathrm{Cz}$ where $\mathrm{Cx}=$ Concentration of $\mathrm{AMD}$ in $\mathrm{g} / 1000 \mathrm{ml}$, $\mathrm{Cy}=$ Concentration of IND in $\mathrm{g} / 1000 \mathrm{ml}, \quad \mathrm{Cz}=$ Concentration of PD in $\mathrm{g} / 1000 \mathrm{ml}, \quad \mathrm{A}_{1}=$ Absorbance of mixture at $\lambda_{1}, \quad \mathrm{~A}_{2}=$ Absorbance of mixture at $\lambda_{2}, \quad \mathrm{~A}_{3}=$ Absorbance of mixture at $\lambda_{3}, \quad \mathrm{ax}_{1}=$
Absorptivity of AMD at $\lambda_{1} \quad \quad \mathrm{ax}_{2}=$ Absorptivity of AMD at $\lambda_{2}, \quad \mathrm{ax}_{3}=$ Absorptivity of AMD at $\lambda_{3}$, $\mathrm{ay}_{2}=$ Absorptivity of IND at $\lambda_{2}, \quad \mathrm{ay}_{3}=$ Absorptivity of IND at $\lambda_{3} \quad \mathrm{az}_{3}=$ Absorptivity of PD at $\lambda_{3}$

\section{Bench top stability of sample solution:}

The bench top stability was determined by using the mixed standard solution. About $0.5 \mathrm{ml}$ of the mixed standard solution of drugs was transferred into a $25 \mathrm{ml}$ volumetric flask and the final volume was made up with distilled water. This solution was kept on the bench top at room temperature and absorbance was recorded against the blank at predetermined wavelengths for time intervals up to $24 \mathrm{~h}$. From the absorbance values, the percentage purity of the drugs was calculated to determine the stability period on bench top.

\section{RESULTS AND DISCUSSION:}

The choice of the diluent was based upon the solubility of the drugs. The drugs were completely soluble in methanol and partially soluble in water. Hence, methanol was used as a solvent to prepare the stock solution and distilled water was used to prepare subsequent dilutions.

The analytical wavelengths were selected by scanning the standard solutions of AMD, IND and PD $(10 \mu \mathrm{g} / \mathrm{ml}$ each) in the range of 200-400 nm against blank. From the overlain spectra (fig. 1) the wavelengths chosen for analysis were as follows: $\lambda_{1}=365 \mathrm{~nm}$ : absorbance due to AMD (absorbance due to other two drugs was nil at this wavelength), $\lambda_{2}=245 \mathrm{~nm}$ : absorbance of IND (corrected for absorbance due to AMD), $\lambda_{3}=204 \mathrm{~nm}$ : absorbance of PD (corrected for absorbances due to AMD and IND). Absorptivity values for the drugs were calculated using the absorbance values recorded for the working standard solutions of drugs at their predetermined wavelengths. The calculated mean absorptivity $\left(\mathrm{lg}^{-1} \mathrm{~cm}^{-1}\right)$ values for the drugs at different wavelengths

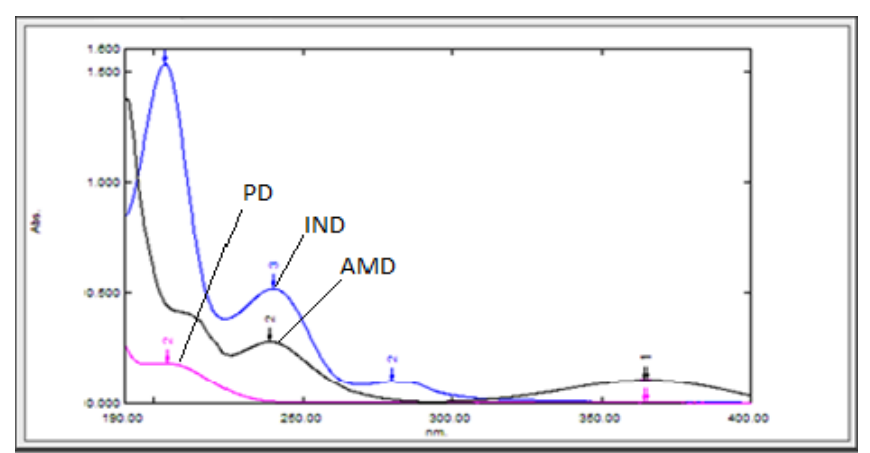

Fig. 1: Overlain UV spectra for AMD (amlodipine), IND (indapamide), PD (perindopril) 


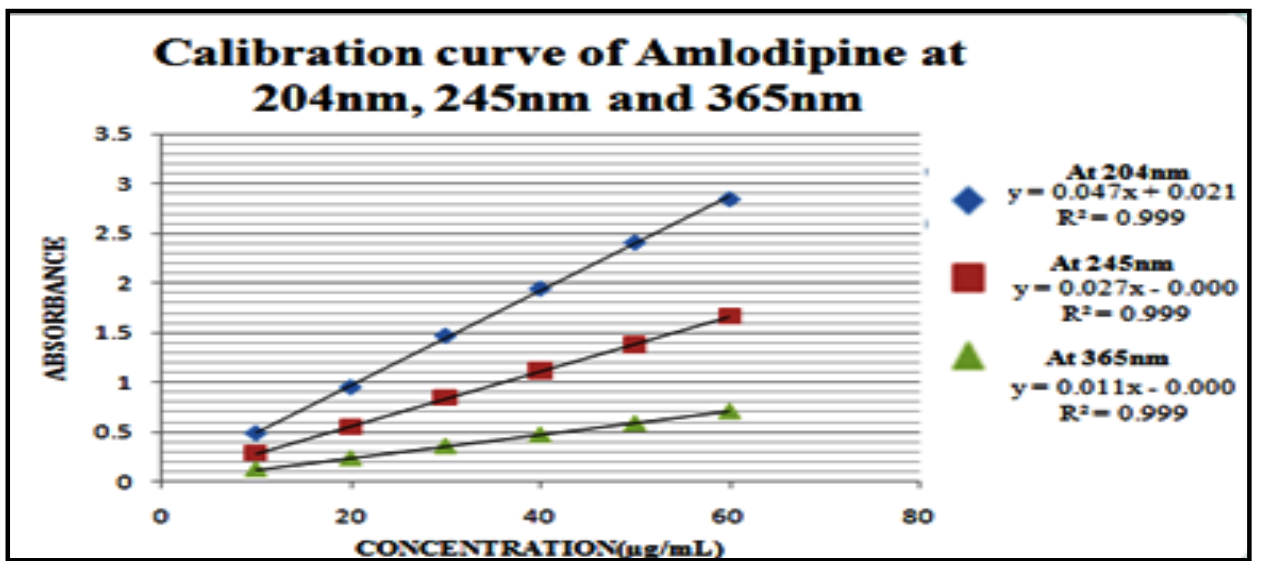

Fig. 2: Calibration curve for amlodipine at $204 \mathrm{~nm}, 245 \mathrm{~nm}$ and $365 \mathrm{~nm}$

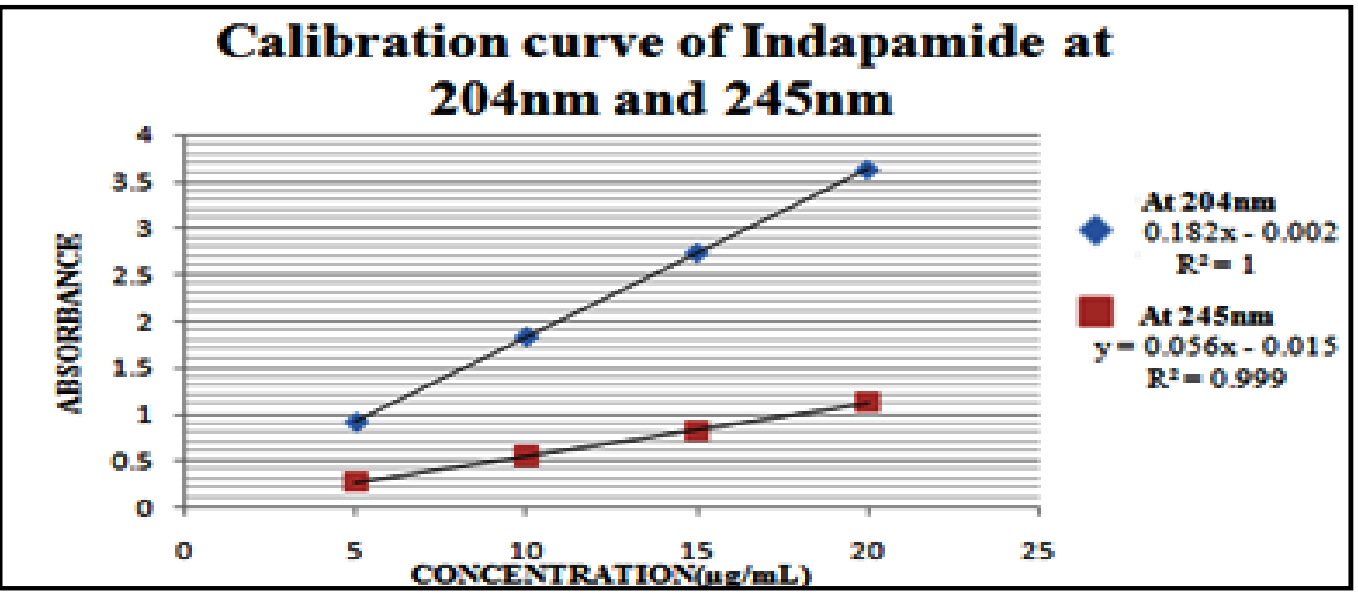

Fig. 3: Calibration curve for indapamide at $204 \mathrm{~nm}$ and $245 \mathrm{~nm}$

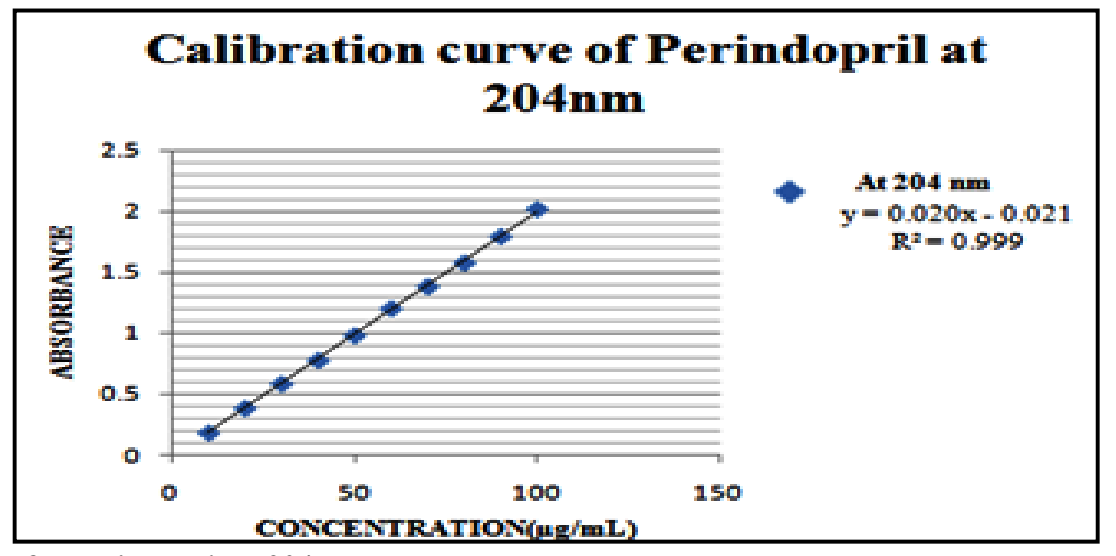

Fig. 4: Calibration curve for perindopril at $204 \mathrm{~nm}$

were found to be $\mathrm{a}_{\mathrm{x} 1}=11.75, \mathrm{a}_{\mathrm{x} 2}=27.70$ and $\mathrm{a}_{\mathrm{x} 3}=48.08$ for AMD, $\mathrm{a}_{\mathrm{y} 2}=54.80, \mathrm{a}_{\mathrm{y} 3}=181.90$ for IND and $\mathrm{a}_{\mathrm{z} 3}=19.60$ for PD.

Linearity range for each drug was obtained by plotting calibration curves at predetermined wavelengths. The calibration plots for the drugs are displayed in fig. 2, 3 and 4. Good correlation between the absorbance and concentration of the drugs was obtained in the concentration range $10-60 \mu \mathrm{g} / \mathrm{ml}$ for $\mathrm{AMD}$,
5-20 $\mu \mathrm{g} / \mathrm{ml}$ for IND and $10-100 \mu \mathrm{g} / \mathrm{ml}$ for PD. The results of linearity for AMD, IND and PD are given in Tables 1, 2 and 3 respectively.

Precision was carried out by analysing the mixed standard solution of drugs in triplicate against the blank thrice a day for intraday studies and on three consecutive days in triplicate for interday precision analysis. The results as depicted in Table 4 and 5 gave percentage relative standard deviation (RSD) values of less than $2 \%$. 
The accuracy of the method was determined by performing percentage recovery at three levels: $80 \%$, $100 \%$ and $120 \%$. As seen in Table 6,7 and 8 the mean percentage recoveries for AMD, IND and PD were found to be within the acceptance limit of 98-102\%.

TABLE 1: SUMMARY OF LINEARITY DATA FOR AMLODIPINE

\begin{tabular}{lccc}
\hline Parameters & At $204 \mathrm{~nm}$ & At $245 \mathrm{~nm}$ & At $365 \mathrm{~nm}$ \\
\hline Beer's law & $10-60 \mu \mathrm{g} / \mathrm{ml}$ & $10-60 \mu \mathrm{g} / \mathrm{ml}$ & $10-60 \mu \mathrm{g} / \mathrm{ml}$ \\
range & $\mathrm{y}=0.047 \mathrm{x}$ & $\mathrm{y}=0.027 \mathrm{x}$ & $\mathrm{y}=0.011 \mathrm{x}$ \\
Regression & -0.021 & -0.000 & -0.000 \\
equation & 0.047 & 0.027 & 0.011 \\
Slope (b) & -0.021 & 0.000 & 0.000 \\
Intercept (c) & 0.999 & 0.999 & 0.999 \\
Correlation & & & \\
Coefficient $\left(\mathrm{r}^{2}\right)$ & & &
\end{tabular}

TABLE 2: SUMMARY OF LINEARITY DATA FOR INDAPAMIDE

\begin{tabular}{lcc}
\hline Parameters & At $204 \mathrm{~nm}$ & At $245 \mathrm{~nm}$ \\
\hline Beer's law range & $5-20 \mu \mathrm{g} / \mathrm{ml}$ & $5-20 \mu \mathrm{g} / \mathrm{ml}$ \\
Regression equation & $\mathrm{y}=0.182 \mathrm{x}-0.002$ & $\mathrm{y}=0.056 \mathrm{x}-0.015$ \\
Slope (b) & 0.182 & 0.056 \\
Intercept (c) & -0.002 & -0.015 \\
Correlation coefficient & 1.000 & 0.999 \\
$\left(\mathrm{r}^{2}\right)$ & & \\
\hline
\end{tabular}

TABLE 3: SUMMARY OF LINEARITY DATA FOR PERINDOPRIL

\begin{tabular}{lc}
\hline Parameters & At $204 \mathrm{~nm}$ \\
\hline Beer's law range & $10-100 \mu \mathrm{g} / \mathrm{ml}$ \\
Regression equation & $\mathrm{y}=0.020 \times-0.021$ \\
Slope (b) & 0.020 \\
Intercept (c) & -0.021 \\
Correlation coefficient $\left(\mathrm{r}^{2}\right)$ & 0.999 \\
\hline
\end{tabular}

Hence the developed method was found to be accurate.

LOD and LOQ were calculated using slope and standard deviation response from the calibration curves of drugs at their respective wavelengths. The results as depicted in Table 9 show that the method was sensitive.

The robustness of the method was determined by introducing deliberate changes in the experimental conditions during the analysis of mixed standard solution of drugs, namely use of different instrument, change of analyst and by altering composition of diluent. The results as depicted in Table 10 show that the deliberate changes do not affect the results of analysis as percentage purity was found to be within the acceptance criteria of 90-110\%. Hence the developed UV method was found to be robust.

The synthetic mixture of drugs was analyzed at predetermined wavelengths i.e. $\lambda_{1}, \lambda_{2}$ and $\lambda_{3}$ in triplicate and the respective absorbance values were noted as $A_{1}$, $\mathrm{A}_{2}$ and $\mathrm{A}_{3}$. The percentage purity of AMD, IND and PD were found to be $99.70 \%, 103.20 \%$ and $97.80 \%$ respectively, which comply with the acceptance criteria of $90-110 \%$. The results are depicted in Table 11.

For bench top stability, the absorbance of the mixed standard solution kept on the bench top at room temperature was recorded every hour till $6 \mathrm{~h}$ and then at $24 \mathrm{~h}$. Stability of the sample solution was determined by calculating the percentage purity. The results as depicted in Table 12 show percentage purity in the range of $90-110 \%$ for a period of up to $3 \mathrm{~h}$. Hence the solution was found to be stable for a period of $3 \mathrm{~h}$ on bench top.

TABLE 4: INTRADAY PRECISION DATA

\begin{tabular}{|c|c|c|c|c|c|c|}
\hline \multirow[t]{2}{*}{ Concentration of drugs $(\mu \mathrm{g} / \mathrm{ml})$} & \multicolumn{3}{|c|}{ Absorbance of mixed standard } & \multicolumn{3}{|c|}{ Concentration obtained $(\mu \mathrm{g})$} \\
\hline & At & At & At & & & \\
\hline & 365 & 245 & 204 & AMD & IND & PD \\
\hline & $\mathrm{nm}$ & $\mathrm{nm}$ & $\mathrm{nm}$ & & & \\
\hline & 0.119 & 0.420 & 1.140 & 10.10 & 2.54 & 10.20 \\
\hline \multirow{3}{*}{$10 \mu \mathrm{g} / \mathrm{ml}$ of $A M D$} & 0.118 & 0.420 & 1.150 & 10.04 & 2.58 & 10.10 \\
\hline & 0.117 & 0.410 & 1.130 & 10.00 & 2.43 & 10.50 \\
\hline & 0.119 & 0.420 & 1.140 & 10.10 & 2.54 & 10.20 \\
\hline \multirow{4}{*}{$2.5 \mu \mathrm{g} / \mathrm{ml}$ of IND } & 0.118 & 0.420 & 1.160 & 10.04 & 2.58 & 10.60 \\
\hline & 0.119 & 0.420 & 1.140 & 10.10 & 2.54 & 10.20 \\
\hline & 0.120 & 0.430 & 1.160 & 10.20 & 2.60 & 10.03 \\
\hline & 0.119 & 0.420 & 1.150 & 10.10 & 2.54 & 10.30 \\
\hline $10 \mu \mathrm{g} / \mathrm{ml}$ of $\mathrm{PD}$ & 0.119 & 0.420 & 1.140 & 10.10 & 2.54 & 10.20 \\
\hline Average & & & & 10.09 & 2.54 & 10.25 \\
\hline Percentage Purity & & & & $100.9 \%$ & $101.6 \%$ & $102.5 \%$ \\
\hline SD & & & & 0.056 & 0.048 & 0.180 \\
\hline Percentage RSD & & & & $0.55 \%$ & $1.88 \%$ & $1.76 \%$ \\
\hline
\end{tabular}




\begin{tabular}{|c|c|c|c|c|c|c|c|c|c|}
\hline & \multicolumn{3}{|c|}{ Concentration of mixed standard } & \multicolumn{3}{|c|}{ Absorbance of mixed standard } & \multicolumn{3}{|c|}{ Concentration obtained $(\mu \mathrm{g})$} \\
\hline & & & & At & At & At & & & \\
\hline & AMD & IND & PD & 365 & 245 & 204 & AMD & IND & PD \\
\hline & & & & $\mathrm{nm}$ & $\mathrm{nm}$ & $\mathrm{nm}$ & & & \\
\hline & & & & 0.119 & 0.420 & 1.140 & 10.10 & 2.54 & 10.20 \\
\hline \multirow[t]{3}{*}{ Day 1} & & & & 0.118 & 0.410 & 1.140 & 10.04 & 2.41 & 10.60 \\
\hline & & & & 0.119 & 0.420 & 1.150 & 10.10 & 2.54 & 10.32 \\
\hline & & & & 0.119 & 0.420 & 1.140 & 10.01 & 2.54 & 10.20 \\
\hline \multirow[t]{3}{*}{ Day 2} & $10 \mu \mathrm{g} / \mathrm{ml}$ & $2.5 \mu \mathrm{g} / \mathrm{ml}$ & $10 \mu \mathrm{g} / \mathrm{ml}$ & 0.119 & 0.420 & 1.150 & 10.10 & 2.54 & 10.30 \\
\hline & & & & 0.117 & 0.420 & 1.150 & 10.00 & 2.60 & 10.05 \\
\hline & & & & 0.117 & 0.420 & 1.150 & 10.00 & 2.60 & 10.02 \\
\hline \multirow[t]{2}{*}{ Day 3} & & & & 0.118 & 0.420 & 1.160 & 10.04 & 2.58 & 10.60 \\
\hline & & & & 0.120 & 0.430 & 1.160 & 10.20 & 2.60 & 10.03 \\
\hline Average & & & & & & & 10.02 & 2.56 & 10.30 \\
\hline Percentage & & & & & & & $1002 \%$ & $1024 \%$ & $1030 \%$ \\
\hline Purity & & & & & & & 100.210 & $102.4 \%$ & \\
\hline SD & & & & & & & 0.06 & 0.03 & 0.22 \\
\hline Percentage RSD & & & & & & & $0.60 \%$ & $1.17 \%$ & $1.94 \%$ \\
\hline
\end{tabular}

\section{TABLE 6: ACCURACY DATA FOR AMLODIPINE}

\begin{tabular}{lcccccc}
\hline $\begin{array}{l}\text { Volume of mixed } \\
\text { standard added }\end{array}$ & $\begin{array}{c}\text { Spiking } \\
\text { level }\end{array}$ & $\begin{array}{c}\text { Amount } \\
\text { present }(\mathrm{mg})\end{array}$ & $\begin{array}{c}\text { Absorbance at } \\
365 \mathrm{~nm}\end{array}$ & $\begin{array}{c}\text { Amount } \\
\text { recovered }(\mathrm{mg})\end{array}$ & $\begin{array}{c}\text { Percentage } \\
\text { recovery }\end{array}$ & $\begin{array}{c}\text { Mean percentage } \\
\text { recovery }\end{array}$ \\
\hline $0.4 \mathrm{ml}$ & $80 \%$ & 10 & 0.092 & 9.79 & 97.9 & $98.20 \%$ \\
& & & 0.093 & 9.89 & 98.9 & \\
$0.5 \mathrm{ml}$ & & & 0.092 & 9.79 & 97.9 & \\
& $100 \%$ & 12.5 & 0.118 & 12.5 & 100 & $99.84 \%$ \\
& & & 0.118 & 12.5 & 100 & \\
$0.6 \mathrm{ml}$ & \multirow{2}{*}{$120 \%$} & 15 & 0.117 & 12.44 & 99.52 & $102 \%$ \\
& & & 0.145 & 15.42 & 102.3 & \\
& & & 0.144 & 15.31 & 102.1 & \\
\hline
\end{tabular}

TABLE 7: ACCURACY DATA FOR INDAPAMIDE

\begin{tabular}{lcccccc}
\hline $\begin{array}{l}\text { Volume of mixed } \\
\text { standard added }\end{array}$ & $\begin{array}{c}\text { Spiking } \\
\text { level }\end{array}$ & $\begin{array}{c}\text { Amount present } \\
(\mathbf{m g})\end{array}$ & $\begin{array}{c}\text { Absorbance at } \\
\mathbf{2 4 5} \mathbf{n m}\end{array}$ & $\begin{array}{c}\text { Amount recovered } \\
(\mathbf{m g})\end{array}$ & $\begin{array}{c}\text { Percentage } \\
\text { recovery }\end{array}$ & $\begin{array}{c}\text { Mean Percentage } \\
\text { recovery }\end{array}$ \\
\hline & & & 0.330 & 2.55 & 102.00 & \\
$0.4 \mathrm{ml}$ & \multirow{2}{*}{$20 \%$} & 2.500 & 0.330 & 2.52 & 100.80 & $101.40 \%$ \\
& & & 0.328 & 2.53 & 101.30 & \\
$0.5 \mathrm{ml}$ & \multirow{2}{*}{$100 \%$} & \multirow{2}{*}{3.125} & 0.413 & 3.08 & 98.40 & \\
& & & 0.414 & 3.10 & 99.20 & $99.46 \%$ \\
& & & 0.413 & 3.15 & 100.80 & \\
$0.6 \mathrm{ml}$ & \multirow{2}{*}{3.750} & 0.510 & 3.84 & 102.30 & \\
& & & 0.500 & 3.66 & 102.30 & $100.86 \%$ \\
\hline
\end{tabular}

A novel and simple UV absorbance correction method has been developed for the simultaneous analysis of AMD, IND and PD in combination. The developed UV spectroscopic method employed water as diluent after the preparation of stock solutions in methanol. The three wavelengths chosen for the estimation of drugs were $365 \mathrm{~nm}$ for AMD as absorbances due to other two drugs were nil at this wavelength, $245 \mathrm{~nm}$ for IND (corrected for absorbance due to AMD) and $204 \mathrm{~nm}$ for PD (corrected for absorbances due to AMD and IND). Method validation was done as per International Conference on Harmonisation (ICH) guidelines. 
www.ijpsonline.com

TABLE 8: ACCURACY DATA FOR PERINDOPRIL

\begin{tabular}{|c|c|c|c|c|c|c|}
\hline $\begin{array}{l}\text { Volume of mixed } \\
\text { standard added }\end{array}$ & Spiking level & $\begin{array}{c}\text { Amount present } \\
(\mathrm{mg})\end{array}$ & $\begin{array}{c}\text { Absorbance at } \\
204 \mathrm{~nm}\end{array}$ & $\begin{array}{l}\text { Amount recovered } \\
(\mathrm{mg})\end{array}$ & $\begin{array}{l}\text { Percentage } \\
\text { recovery }\end{array}$ & $\begin{array}{c}\text { Mean Percentage } \\
\text { recovery }\end{array}$ \\
\hline & & & 0.911 & 10.04 & 100.40 & \\
\hline \multirow[t]{3}{*}{$0.4 \mathrm{ml}$} & $80 \%$ & 10 & 0.910 & 10.36 & 103.60 & $102.00 \%$ \\
\hline & & & 0.910 & 10.36 & 103.60 & \\
\hline & & & 1.130 & 12.70 & 101.60 & \\
\hline \multirow[t]{3}{*}{$0.5 \mathrm{ml}$} & $100 \%$ & 12.5 & 1.120 & 12.00 & 96.00 & $98.72 \%$ \\
\hline & & & 1.130 & 12.32 & 98.56 & \\
\hline & & & 1.353 & 15.40 & 102.60 & \\
\hline \multirow[t]{2}{*}{$0.6 \mathrm{ml}$} & $120 \%$ & 15 & 1.352 & 14.60 & 96.00 & $100.40 \%$ \\
\hline & & & 1.353 & 15.40 & 102.60 & \\
\hline
\end{tabular}

TABLE 9: LOD AND LOQ VALUES FOR DRUGS

\begin{tabular}{lcccccc}
\hline & \multicolumn{3}{c}{ Drugs } \\
\cline { 2 - 6 } & At $365 \mathrm{~nm}$ & At $245 \mathrm{~nm}$ & At $204 \mathrm{~nm}$ & At $245 \mathrm{~nm}$ & At $204 \mathrm{~nm}$ & At $204 \mathrm{~nm}$ \\
\cline { 2 - 5 }$(\mu \mathrm{g} / \mathrm{ml})$ & 0.950 & 0.095 & 1.680 & 0.630 & 0.170 & 1.860 \\
LOQ $(\mu \mathrm{g} / \mathrm{ml})$ & 2.890 & 0.290 & 5.100 & 1.920 & 0.520 & 5.600 \\
\hline
\end{tabular}

TABLE 10: ROBUSTNESS DATA

\begin{tabular}{|c|c|c|c|c|c|c|c|c|c|c|c|c|}
\hline Sr. No & \multicolumn{3}{|c|}{$\begin{array}{l}\text { Concentration of } \\
\text { mixed standard }\end{array}$} & \multicolumn{3}{|c|}{$\begin{array}{l}\text { Absorbance of mixed } \\
\text { standard }\end{array}$} & \multicolumn{3}{|c|}{$\begin{array}{l}\text { Amount found } \\
\text { (mg) }\end{array}$} & \multicolumn{3}{|c|}{ Percentage Purity } \\
\hline & $A M D$ & IND & PD & $\begin{array}{c}\text { At } \\
365 \\
\mathrm{~nm}\end{array}$ & $\begin{array}{c}\text { At } \\
245 \\
n m\end{array}$ & $\begin{array}{c}\text { At } \\
204 \\
\mathrm{~nm}\end{array}$ & AMD & IND & PD & AMD & IND & PD \\
\hline 1 & & & & 0.118 & 0.410 & 1.130 & 10.04 & 2.41 & 10.60 & 100.4 & 96.4 & 106.0 \\
\hline 2 & 10 & 2.5 & 10 & 0.119 & 0.402 & 1.150 & 10.10 & 2.50 & 10.30 & 101.0 & 101.6 & 103.0 \\
\hline 3 & $\mu \mathrm{g} / \mathrm{ml}$ & $\mu \mathrm{g} / \mathrm{ml}$ & $\mu \mathrm{g} / \mathrm{ml}$ & 0.118 & 0.420 & 1.140 & 10.04 & 2.06 & 10.10 & 100.4 & 103.2 & 101.0 \\
\hline Mean & & & & & & & & & & $100.6 \%$ & $100.4 \%$ & $103.3 \%$ \\
\hline
\end{tabular}

TABLE 11: ASSAY OF SYNTHETIC MIXTURE

\begin{tabular}{|c|c|c|c|c|c|c|c|c|c|}
\hline \multirow[t]{2}{*}{ Sr. No } & \multicolumn{3}{|c|}{ Absorbance of mixed standard } & \multicolumn{3}{|c|}{$\begin{array}{l}\text { Amount found } \\
(\mathrm{mg})\end{array}$} & \multicolumn{3}{|c|}{$\begin{array}{c}\text { Percentage } \\
\text { Purity }\end{array}$} \\
\hline & $\begin{array}{c}\text { At } \\
365 \mathrm{~nm}\end{array}$ & $\begin{array}{c}\text { At } \\
245 \mathrm{~nm}\end{array}$ & $\begin{array}{c}\text { At } \\
204 \mathrm{~nm}\end{array}$ & AMD & IND & PD & $A M D$ & IND & PD \\
\hline 1 & 0.117 & 0.407 & 1.140 & & & & & & \\
\hline 2 & 0.116 & 0.406 & 1.130 & 12 & 322 & 12 2 & 007 & 102 & 078 \\
\hline 3 & 0.117 & 0.407 & 1.140 & 12.44 & $3.2 L$ & $12 . \angle U$ & 99.1 & 103.2 & 91.0 \\
\hline Mean & 0.117 & 0.407 & 1.140 & & & & & & \\
\hline
\end{tabular}

TABLE 12: BENCH TOP STABILITY OF MIXED STANDARD

\begin{tabular}{|c|c|c|c|c|c|c|c|c|c|}
\hline \multirow{2}{*}{$\begin{array}{l}\text { Time } \\
\text { interval } \\
\text { (h) }\end{array}$} & \multicolumn{3}{|c|}{ Concentration of mixed standard } & \multicolumn{3}{|c|}{ Absorbance of mixed standard } & \multicolumn{3}{|c|}{ Percentage Purity } \\
\hline & AMD & IND & PD & $\begin{array}{c}\text { At } \\
365 \mathrm{~nm}\end{array}$ & $\underset{245 \mathrm{~nm}}{\text { At }}$ & $\begin{array}{c}\text { At } \\
204 \mathrm{~nm}\end{array}$ & AMD & IND & PD \\
\hline 1 & & & & 0.122 & 0.427 & 1.142 & 103.0 & 103.2 & 90.1 \\
\hline 2 & & & & 0.122 & 0.426 & 1.139 & 103.0 & 102.0 & 91.0 \\
\hline 3 & & & & 0.122 & 0.426 & 1.138 & 103.0 & 102.0 & 90.4 \\
\hline 4 & $10 \mu \mathrm{g} / \mathrm{ml}$ & $2.5 \mu \mathrm{g} / \mathrm{ml}$ & $10 \mu \mathrm{g} / \mathrm{ml}$ & 0.122 & 0.425 & 1.134 & 103.0 & 102.0 & 89.3 \\
\hline 5 & & & & 0.122 & 0.420 & 1.127 & 103.0 & 102.0 & 87.3 \\
\hline 6 & & & & 0.118 & 0.420 & 1.127 & 100.4 & 101.8 & 88.5 \\
\hline 24 & & & & 0.110 & 0.400 & 1.100 & 97.8 & 101.9 & 81.1 \\
\hline
\end{tabular}


The linearity range for the drugs were $10-60 \mu \mathrm{g} / \mathrm{ml}$, $5-20 \mu \mathrm{g} / \mathrm{ml}$ and $10-100 \mu \mathrm{g} / \mathrm{ml}$ for AMD, IND and PD respectively. The method was found to be sensitive, accurate, precise and robust. The percentage assay of AMD, IND and PD in synthetic mixture was found to be $99.70 \%, 103.20 \%$ and $97.80 \%$ respectively, which were within the acceptance criteria. Hence the developed method is a cost effective analytical tool for the simultaneous estimation of the three drugs in combination by UV spectroscopy.

\section{Acknowledgements:}

The authors are thankful to Alkem Laboratories Ltd., Mumbai, Glenmark Pharmaceuticals, Goa and Adock Ingram Ltd., Bangalore for providing the gift samples of amlodipine besylate, perindopril tert-butyl amine and indapamide respectively.

\section{Conflict of Interests:}

The authors declare no conflict of interest.

\section{REFERENCES}

1. DrugBank, Pharmaceutical Knowledge Base, API Integrations. Drugbank.com; 2020.

2. Tripathi KD. Essentials of Medical Pharmacology. $7^{\text {th }}$ ed. New Delhi: Jaypee Brothers Medical Publishers (P) Ltd; 2013.

3. Ali NW, Abdelwahab NS, Zaki MM, Abdelkawy M. Validated Chromatographic Methods for simultaneous determination of amlodipine besylate and perindopril arginine in binary mixtures and in pharmaceutical dosage form. J Chromatogr Sep Tech 2012;3(4):134-9.

4. Soujanya S. Method development and validation of simultaneous estimation of perindopril and indapamide in tablet by RP-HPLC method. Indo Am J Pharm Res 2017;7(9):390-7.

5. El-Bagary RI, Elkady EF, Mowaka S, Attallah MA. A validated HPLC method for simultaneous determination of perindopril arginine, amlodipine, and indapamide: application in bulk and in different pharmaceutical dosage forms. J AOAC Int 2017;100(4):992-9.

6. Joseph J, Philip B, Sundarapandian M. Method development and validation for simultaneous estimation of perindopril erbumine and indapamide by RP-HPLC in pharmaceutical dosage forms. Int J Pharm Pharm Sci 2011;3(4):288-93.

7. Patel DB, Mehta FA, Bhatt KK. Simultaneous estimation of amlodipine besylate and indapamide in a pharmaceutical formulation by a high performance liquid chromatographic (RP-HPLC) method. Sci Pharm 2012;80(3):581-90.

8. Swamy GK, Kumar JMR, Seshagiri Rao JVLN. Development and validation of a novel stability indicating RP-HPLC method for simultaneous estimation of perindopril, indapamide and amlodipine in bulk and combined tablet dosage forms. World $\mathrm{J}$ Pharm Res 2015;4(6):2440-56.

9. Masthannamma SK, Tejaswini IS, Saidulu P, Rambabu G. Simultaneous equation method and absorption correction method for the estimation of perindopril erbumine and amlodipine besylate in bulk and in combined tablet dosage form using UV Spectophotometry. Int J Pharm Sci Res 2015;6(6):2484-90.

10. Patel MP, Hasumati R, Shah N. First order derivative spectrophotometric method for simultaneous estimation of Amlodipine besylate and Indapamide in combined pharmaceutical dosage form. Asian $J$ Res Chem 2014;17(7):615-8.

11. Amin A, Parikh N. Simultaneous estimation of amlodipine and indapamide in combined dosage form using derivative spectrophotometric method. Int $\mathrm{J}$ Pharma Bio Sci 2012;1(3):204-19.

12. Modi DK, Patel CN. Development and validation of spectrophotometric method for simultaneous estimation of perindopril and indapamide in combined dosage form by absorbance correction method. Int $\mathrm{J}$ Pharmatech Res 2010;2(1):411-6.

13. Prajapati J, Patel MB, Prajapati RJ, Prajapati NA. Simultaneous determination of perindopril erbumine and amlodipine besylate by absorption factor method. Int J Appl Biol Pharm 2011;2(3):230-3.

14. Shah RN, Gandhi DB, Patel MM. Simultaneous determination of amlodipine besylate and indapamide in tablet dosage form by absorption correction method and First order derivative UV spectroscopy. Int J PharmTech Res 2012;4(3):1018-24.

15. Nazareth C, Shivakumar B, Reddy P, Gurupadayya BM. Development and validation of HPTLC method for simultaneous analysis of olmesartan and indapamide in bulk drug and combined tablet formulation. Indo Am J Pharm Res 2013;3(12):1709-15.

16. Housheh S, Jdeed L. Analytical methods of perindopril, review. World J Pharm Res 2017;6(4):1563-75. 